\section{Frente nacional contra a privatização e sua luta em defesa da saúde pública estatal}

\section{Maria Inês Souza Bravo*}

A ampliação das Organizações Sociais em vários estados do Brasil propiciou a articulação dos Fóruns de Saúde do Rio de Janeiro, Paraná, Alagoas, São Paulo e Londrina, em maio de 2010, para compor uma Frente Nacional pela procedência da Ação Direta de Inconstitucionalidade (ADIn) n. 1.923/98, contra a Lei n. 9.637/98, que "dispõe sobre a qualificação de entidades como organizações sociais, a criação do Programa Nacional de Publicização, a extinção dos órgãos e entidades que menciona e a absorção de suas atividades por organizações sociais, e dá outras providências", e contra a alteração do inciso XXIV do artigo 24 da

\footnotetext{
* Assistente social, doutora em Serviço Social (PUC/SP) e pós-doutora em Serviço Social pela UFRJ, professora aposentada da UFRJ, professora adjunta da Faculdade de Serviço Social da Universidade do Estado do Rio de Janeiro - UERJ; procientista da UERJ — Rio de Janeiro/RJ, Brasil, e coordenadora dos projetos "Políticas Públicas de Saúde: o potencial dos Conselhos do Rio de Janeiro" e "Saúde, Serviço Social e movimentos sociais", financiado pelo CNPq e Uerj. E-mail: mibravo@uol.com.br.
}

Lei n. 8.666/93, com redação dada pelo artigo $1^{\circ}$ da Lei n. 9.648/98, que permite a dispensa de licitação para a celebração de contratos de prestação de serviços com as organizações sociais (OS).

As ações desenvolvidas por esses Fóruns de Saúde tem sido: pautar junto ao Supremo Tribunal Federal (STF) a importância da votação favorável à Adin n. 1923/98, por intermédio de audiências com os ministros; divulgar carta nacional pedindo a aprovação da Adin assinada por entidades e movimentos sociais do país (a carta pode ser vista em $<$ http://www.pelasaude.blogspot.com $>$ e tem 316 assinaturas de entidades até o dia 9/1/2011); constituir campanha por meio de abaixo-assinado digital, a fim de mobilizar a população e explicitar os problemas de mercantilização do serviço público. Veja o abaixo-assinado com 5.352 assinaturas em: $<\mathrm{http} / / / \mathrm{www}$. pelasaude.blogspot.com>.

Como desdobramentos dessa mobilização foram previstas pelos respectivos Fóruns as seguintes ações:

- Dia nacional de luta contra as Organizações Sociais (OS);

— realização de um seminário nacional com a presença dos Fóruns de Saúde e das entidades nacionais que estão participando mais diretamente da frente;

- mobilização e articulação com outros fóruns que estão surgindo nos diversos estados, como o Fórum em Defesa da Saúde do Rio Grande do Norte.

A importância da manifestação contra as Organizações Sociais se insere na defesa do Sistema Único de Saúde (SUS), 
previsto na Constituição de 1988, voltado para os interesses da população, e não para sua privatização.

As Organizações Sociais (OS) e as Organizações da Sociedade Civil de Interesse Público (Oscip) pretendem transformar a gestão pública e surgem nos anos 1990 por meio da chamada Reforma do Estado do governo FHC que teve como protagonista Bresser Pereira.

Franco (1998), ao analisar as Organizações Sociais, apresenta seis razões contrárias a essa proposição e que se contrapõem ao SUS constitucional:

— quebra do "sistema", na forma concebida originalmente pelo SUS;

- extinção do quadro de servidores públicos da Saúde, nos estabelecimentos gerenciados pelas OS;

— gestão dos recursos humanos centralizadora e normativa;

— a saúde deixa de ser um direito público e passa a ser assumida pelo mercado;

— não há possibilidade de um novo modelo de assistência;

— as OS não valorizam o controle social.

Rezende (2008) também faz diversas críticas às Organizações Sociais e às Organizações da Sociedade Civil de Interesse Público, destacando os seguintes aspectos: as ações serão focalizadas, não haverá participação da comunidade nem controle social, a descentralização das ações será para a iniciativa privada.

Como proposta dos Fóruns de Saúde citados, foi realizado o Seminário Nacional "20 anos de SUS: Lutas sociais contra a privatização e em defesa da saúde pública estatal", na Uerj/RJ, nos dias 22 e 23 de novembro de 2010, com a presença de movimentos sociais, sindicatos, centrais sindicais, núcleos e/ou setoriais de partidos políticos, professores e estudantes vinculados à saúde, totalizando quatrocentos participantes.

Esse seminário teve por objetivo fortalecer a articulação nacional entre os Fóruns de Saúde dos diversos estados, a articulação com outras entidades, bem como a mobilização para a ampliação do movimento para todos os estados brasileiros por meio da criação de Fóruns de Saúde com intenção de defender a saúde pública estatal.

$\mathrm{Na}$ plenária final do seminário foi criada a Frente Nacional contra a Privatização da Saúde com uma coordenação nacional composta por diversas entidades, ${ }^{1}$ que tem o propósito de articular as ações da frente, ampliar o debate e estimular a criação de fóruns em outros estados.

A Frente está enfrentando, no momento, duas grandes medidas contrárias ao Sistema Único de Saúde (SUS) previsto na Constituição de 1988, além das lutas já encaminhadas:

- A Lei Complementar aprovada em 22/12/2010, na Assembleia Legislativa de

1. Abepss, Andes, Asfoc, Central de Movimentos Populares, CFESS, Conselho Nacional de Saúde, CSPConlutas, CTB, Executiva Nacional dos Estudantes de Enfermagem, Fasubra, Fenasps, Fentas, Fórum Nacional de Residentes, Intersindical, MST, Seminário Livre pela Saúde: os Fóruns de Saúde já existentes: Rio de Janeiro, Alagoas, São Paulo, Paraná, Londrina, Rio Grande do Norte e os setoriais e/ou núcleos dos partidos políticos: PSOL, PCB, PSTU, PT, Consulta Popular. 
São Paulo, que permite que as Organizações Sociais utilizem até $25 \%$ de sua capacidade para atender pacientes privados com ou sem planos de saúde. Isto significa a utilização de critérios de discriminação econômica em vez de critérios de prioridade baseados na necessidade de saúde. $\mathrm{O}$ investimento feito com recursos públicos, extraído dos impostos pagos por toda a população, será disponibilizado de forma não igualitária, permitindo a entrada diferenciada no sistema de saúde para os que têm fontes privadas de financiamento.

- A Medida Provisória n. 520, de 31 de dezembro de 2010, que cria a Empresa Brasileira de Serviços Hospitalares (EBSH), uma empresa pública com personalidade jurídica privada, sem qualquer espaço de controle social, conforme preconizado pela legislação do SUS. Esta empresa tem a possibilidade de administrar não só os hospitais universitários, mas qualquer unidade hospitalar no âmbito do SUS por meio de contrato de gestão. A EBSH, como prevê a proposta de Fundações Estatais de Direito Privado, poderá contratar funcionários por CLT e por contrato temporário de até dois anos, acabando com a estabilidade e implementando a lógica da rotatividade, típica do setor privado, comprometendo a continuidade e a qualidade do atendimento. Está previsto também a criação de previdência privada para os seus funcionários (Cislaghi 2011). ${ }^{2}$

2. Para ler a MP na íntegra, acesse <http://www. sinditest.org.br/portal/noticias/dilma-assume-com-criacao-de-nova-estatal-para-educacao-e-saude/> .
Considera-se, portanto, na atual conjuntura, fundamental a Frente Nacional através da articulação entre diversos movimentos sociais e entidades com vistas à construção de resistência às medidas regressivas quanto aos direitos sociais e de mercantilização das políticas sociais. A mobilização em torno da viabilização do Projeto de Reforma Sanitária, construído nos anos 1980 no Brasil, é uma estratégia para a defesa da saúde concebida como melhores condições de vida e de trabalho, bem como para a construção de uma sociedade justa e igualitária.

Artigo recebido em dez./2010

Aprovado em dez./2010

\section{Referências bibliográficas}

CISLAGHI, J. F. MP 520/2010: Golpe na saúde pública e na democracia. Rio de Janeiro, 2011. (Mimeo.)

FRANCO, Túlio Batista. As Organizações Sociais e o SUS, junho de 1998. Disponível em: $<$ www.datasus.gov.br/cns/temas/as_organizações_sociais_e_o_sus.htm>. Acesso em: 12 mar. 2010.

REZENDE, Conceição Aparecida Pereira. O modelo de gestão do SUS e as ameaças do Projeto Neoliberal. In: BRAVO, Maria Inês Souza et al. (Orgs.). Politica de saúde na atual conjuntura: modelos de gestão e agenda para a Saúde. 2. ed. Rio de Janeiro: Rede Sirius/ Adufrj-SSind, 2008. 